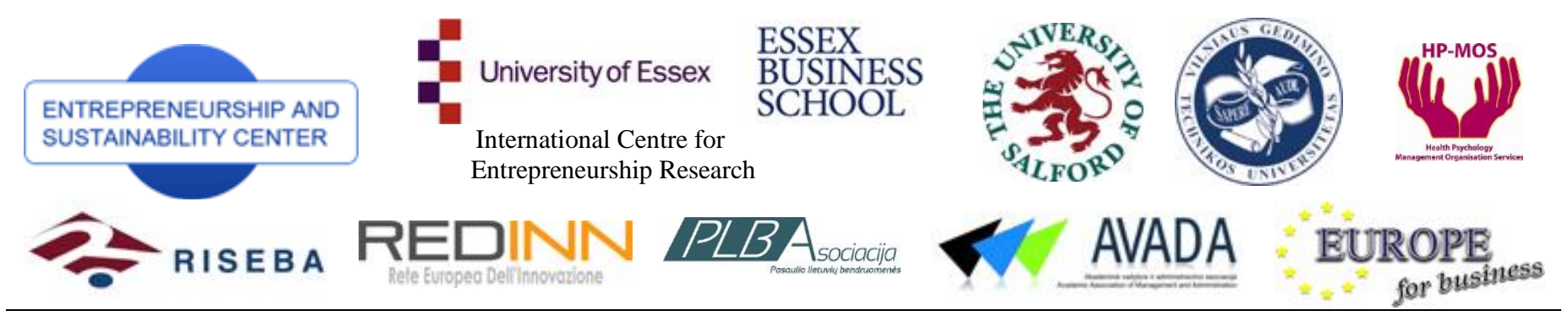

ENTREPRENEURSHIP AND SUSTAINABILITY ISSUES

ISSN 2345-0282 (online) http://jssidoi.org/jesi/aims-and-scope-of-research/

\title{
SUSTAINABLE ENTREPRENEURSHIP: LOCALIZATION, ACQUIRING AND USE OF KNOWLEDGE SOURCES IN COMPETITIVE ORGANIZATION
}

\author{
Irena Figurska \\ Pomeranian University \\ Westerplatte 64, 76-200 Stupsk, Poland \\ E-mails: irenafigurska@vp.pl
}

Received 20 January 2014; accepted 30 March 2014

\begin{abstract}
Sustainable entrepreneurship leading to competitiveness of a company demands implementation of the activities which are focused on creating, transferring and using knowledge for increasing competitiveness by all organizations. It demands the implementation of procedures connected with knowledge management in companies. One of the processes of knowledge management is localization of internal and external sources of knowledge. The goal of this paper is to present the issues related to the identification and accordingly exploitation of internal and external sources of knowledge in both theoretical and practical aspects. In the first part of this article the main internal and external knowledge sources are described as well as the ways of their visualization. The article also presents the results of research which shows what sources of knowledge are the most and least used by workers in organizations. The practical recommendations related to use of knowledge sources are also presented in the article. The procedure for identifying and acquiring knowledge sources which are useful to the organization and its employees is also described. The final part of the article includes conclusiona arising from theoretical considerations and results of conducted research.
\end{abstract}

Keywords: knowledge, knowledge management, knowledge sources, competitiveness of organization, sustainable entrepreneurship

Reference to this paper should be made as follows: Figurska, I. 2014. Sustainable entrepreneurship: localization, acquiring and use of knowledge sources in competitive organization, Entrepreneurship and Sustainability Issues 1(4): 210-222.

DOI: http://dx.doi.org/10.9770/jesi.2014.1.4(3)

JEL Classifications: D83, M19, M12

\section{Introduction}

Knowledge management at organization directly impacts its competitiveness, which could be perceived as outcome of sustainable entrepreneurship. A bulk of literature is devoted to research area of sustainability (e.g. Grybaitė 2011; Tvaronavičienė, Lankauskienė 2011; Stańczyk 2011; Radović Marković 2011; Dudzevičiūtė, Tvaronavičienė 2011; Tvaronavičienė 2012; Dudzevičiūtė 2012; Lankauskienè, Tvaronavičienė 2012; Tvaronavičienè, Grybaitè 2012; Dudzevičiūtè 2013; Vasiliūnaitė 2014; Makštutis et al. 2012; Lavrinovich et al. 2012; Ercsey 2012; Vosylius et al. 2013; Šileika, Bekerytė 2013; Galan-Ladero et al. 2013; Laužikas, Mokšeckienė 2013; Giriūnienė 2013; Mačiulis, Tvaronavičienė 2013; Wahl, Prause 2013; Laužikas, Krasauskas 2013; De Alencar, Almeida, H. 2013; Baikovs, A.; Zariňš, I. 2013; Antanavičienė 2014; Tvaronavičienė 2014; Prause, Hunke 2014; Caurkubule, Rubanovskis 2014) and entrepreneurship (Wahl, 
Prause 2013; Tvaronavičienė 2014; Raišienė, Jonušauskas 2013; Bhati, Manimala 2011; Baikovs, Zariņ̌ 2013; Dudzevičiūtė 2013, Balkienè 2013; Moskvina 2013, Išoraitė 2013; Bileišis 2014). Role of knpwledge management the process of building a competitive advantage of sustainable entrepreneurial organization can not be underestimated.

Nowadays constant changes in the organization and its environment lead to the situation when localization of knowledge that is necessary to make decisions and take actions becomes a very difficult process. Limited access to knowledge related to important areas of the organization in many companies, especially large ones, is a common problem. Due to the poor flow of information organizations are not infrequently reinventing the wheel even though the right solution is at hand. Therefore transparency of knowledge, which allow workers to reach the required knowledge and use it in the activities should be considered one of the fundamental determinants of the effectiveness of knowledge management. Greater transparency of knowledge also enables to determine existing knowledge gaps and make decisions about ways of their elimination by knowledge acquiring and/or developing. To achieve the state of knowledge transparency in the organization internal and external knowledge sources must be located and presented.

\section{Localization of internal and external knowledge sources}

Knowledge can be located in or outside the organization and come from various market players (Figure 1). If the employees can indicate where valuable knowledge sources are, then they can reach them and try to exploit in their activities. However, if the employees do not know where such knowledge is located, or access to it is complicated, then many of them resign from its searching.

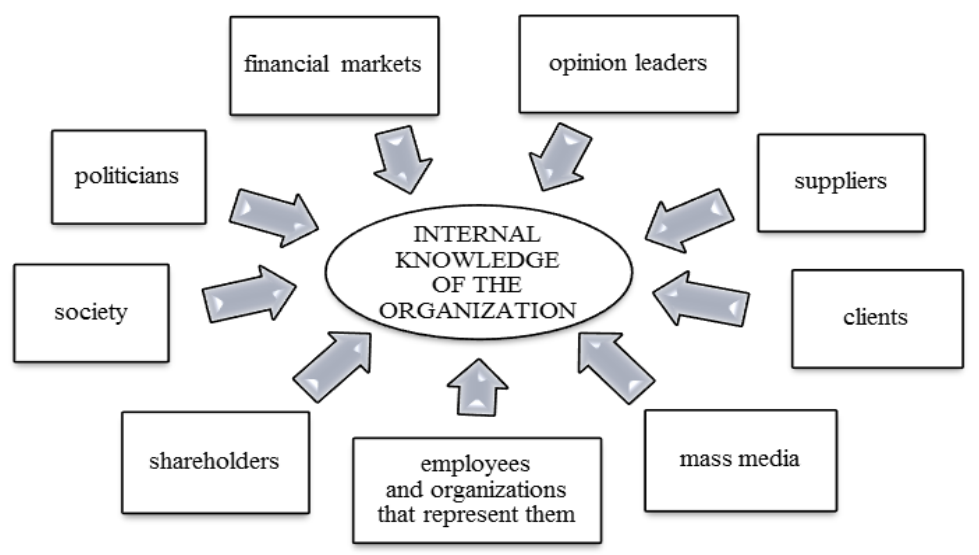

Fig.1. Groups of market players

Source: based on: (Probst et al. 2002: 130)

Knowledge localization is aimed at showing where the sources of knowledge (tacit and explicit, inside and outside the organization) are to enable employees to use them in order to deal with emerging problems. The realization of this process helps to avoid previously made mistakes and long-term seeking for solutions developed in the past, which, however, are not remembered or nobody knows where to look for them. Organizations can use in their activities both internal and external sources of knowledge. Internal sources contain knowledge that is in the possession of the organization and its employees. Current internal knowledge of the organization includes both knowledge that has been developed within the company and knowledge from outside the organization, which has been absorbed in the past and in the unique way combined with the prior knowledge of the company.

The basic internal source of knowledge in every organization is an employees' knowledge stored in their brains, including both their explicit and tacit knowledge. Some pieces of information regarding this knowledge can be found in documentation of human resources department. The superiors, who incessantly observe and assess 
activities of their subordinates are also in possession of their knowledge. However, about possessed tacit knowledge know only employees themselves. Information about the organization can be found in its various departments. They create annual reports, financial statements, marketing plans, business plans, development plans, investment plans, address lists etc., which are necessary sources of knowledge to make right decisions and take right actions in the organization (Sopińska, Wachowiak 2006). The sources of internal explicit knowledge are also organizational documents such as: statutes, regulations, instructions, organizational charts, orders, circulars etc. If they contribute to increase the efficiency of the organization's functioning, they also have an impact on its competitive position in the market. Organizational culture is an important internal source of knowledge about values, norms and habits that are acceptable and desired in the organization. IT tools such as internal data bases, network discussion groups, Intranet etc., if appropriately used, can facilitate the process of retrieving sources of internal codified knowledge. It is worth mentioning that transparency of knowledge in the organisation, which facilitates the localization of its sources, involves some potential dangers. Head-hunters seeking candidates for other organizations have a much easier task, it can also lead to situation in which important knowledge leak out of the organization (Probst et al. 2002).

Using only internal knowledge sources in the process of building competitive position by the organization is not enough. Nowadays even the most innovative organizations require knowledge from beyond their boundaries when developing their innovations (Rigby, Zook 2002). Knowledge that is created outside the organization is called external knowledge.

External knowledge sources include, inter alia (Probst et al. 2002; Tiwana 2003; Figurska 2012):

- clients of the organization - as a source of knowledge about their changing needs, their perception of the company and its products, etc.,

- suppliers - as a source of knowledge about the functioning of other organizations they supply,

- market - providing knowledge about industry trends, new products, activities of competitors, the level of their sales, mergers, new entrances, etc.

- business environment - as a source of knowledge about the directions of economic policy, technologies, changes in society, changes in the law, etc.

- research centres, universities - provide access to information about new technologies and theories, which can shape the capacity of the organization in the long term,

- conferences, seminars, exhibitions - which are a way to verify what competitors are doing and what are the latest innovations in the industry, etc.

- publications - provide the organization with valuable information, which can help in creating new, innovative products, etc.,

- consulting firms - as a source of information in various fields, such as those related to taxes, finances, strategic management, etc.

- knowledge brokers - who can locate the knowledge needed to customers, allowing to carry out a transaction (e.g. providing information on potential partners for joint ventures),

- market research agencies - as a source of knowledge about the results of the market research,

- business competitors - as a source of knowledge about competitive products or services, their growth strategies, etc.,

- politicians - providing information on economic policies etc.,

- media - bringing information on issues that may be important for the functioning of the organization, such as on the actions taken by the government,

- Internet - being today the most common, though not always reliable, the source of information on many different topics,

- best practices - as a source of information about solutions bringing certain benefits, proven in different parts of the organization (units, departments) or in other companies,

- informal contacts of employees.

Not all companies appreciate the importance of information and knowledge derived from external sources. In some of them employees even defend themselves against the inflow of knowledge from the widely understood environment of the organization. New sources of knowledge are often ignored, underestimated or overlooked, 
and the employees choose those of incoming information, that suit their views. On the other hand, not all aforementioned external knowledge sources are equally important to the organization. Thus it is worth using only those sources which provide the organization with knowledge that reflects its needs as well as nurture relations which enable employees to access these important sources of knowledge.

Tremendous amount of information derived from different sources that access organization makes it more and more difficult to differentiate which pieces of information are valuable and which are not. That is why presentation (visualisation) of knowledge sources is becoming more and more significant process. It enables members of the organization to locate important knowledge. "The emerging field of knowledge visualization examines the use of visual representations to improve the management of knowledge on all levels (personal, interpersonal, team, organizational, inter-organizational, and societal). (...) Beyond the mere transport of information or facts, people who employ knowledge visualization aim to create, assess, reference or transfer insights, experiences, attitudes, values, expectations, perspectives, opinions and predictions, and this in a way that enables someone else to re-construct, remember, find or apply these insights correctly" (Eppler, Burkhard 2007).

The most popular methods of visualizing knowledge sources are:

- address books, which include specific categories of data that concerns the members of the organization and/or external experts that cooperate with the organization,

- communication networks which identify who and when the employees refer to when their own knowledge is insufficient to make a decision or solve a problem,

- metaphors, which provide "(...) the path from the understanding of something familiar to something new by carrying elements of understanding from the mastered subject to a new domain" (Eppler, Burkhard 2007),

- knowledge maps which show graphically mutual relations among the intellectual assets existing in the organization, sources of knowledge and its application. Knowledge maps systematize constantly increasing sources of knowledge, improve the transparency of knowledge structure, accessibility to its sources as well as expand the context in which knowledge appears (Eppler 2004; Pepper 1999; Wachowiak 2009).

These briefly described tools facilitate the localization of knowledge and getting to its valuable sources. However, if the process is to proceed efficiently, a person must be appointed to take responsibility for it.

\section{Acquiring knowledge from external sources}

Organization that does not have the knowledge necessary to make specific decisions and take specific actions can acquire it from the environment. In the case of external sources of knowledge the possibility of their use by the organization depends not only on their proper localization, but also on company's knowledge about methods of acquiring knowledge and skills of their use in practice. Knowledge from some external sources (e.g. Internet, informal contacts) can be acquired at a relatively low cost. Acquiring knowledge, not infrequently, is connected with the necessity of buying it on the knowledge markets (Probst et al. 2002). Besides buyers and sellers there are organizations of knowledge brokers on the knowledge markets. Some of them gather knowledge in a specific field, other gather specific information about knowledge possessed by various entities. They are focused on connecting those who need knowledge with those who have it (Kowalczyk, Nogalski 2007).

One of the ways of acquiring knowledge is the employment of new workers that possess desired knowledge. If this process is to be effective a lot of attention must be given to the recruitment and selection of candidates for the job as well as to the creation of transparent and precise criteria of assessment. Knowledge can also be acquired through consulting firms which specialize in specific areas of business activity. Therefore companies gain access to experts' knowledge who are employed there without having to employ them permanently. Organizations can also acquire knowledge from other companies through mergers and takeovers or strategic alliances. Thanks to mergers and takeovers the organizations can grant itself access to new technologies, acquire talented employees, enter new markets for their products etc. As far as strategic alliances are concerned every 
member of the alliance can compensate their weaknesses using material resources, access to various markets, know-how and capital of other companies (Probst et al. 2002). Valuable clients' knowledge can be acquired through personal contacts or market research. Key clients are believed to know weaknesses and strengths of the company's product better that its creators. While acquiring important for the organization knowledge it is vital to maintain contacts with scientists, research centres and institutions of higher education. These contacts can be of informal nature or they can be realized through joint research projects, sponsoring research, participation of practitioners in scientific conferences etc. (Probst et al. 2002). Every employee also acquires knowledge from environment through media, thanks to which they can become acquainted with ideas of people who shape public opinion, learn about new technologies, changes that occur in the local environment etc.

Efficient acquisition of knowledge by organizations can be facilitated by the following: using benchmarking, a system of external training, cooperation with other organizations (internships and apprenticeships), subscription of specialist magazines and business intelligence (Kowalczyk, Nogalski 2007). Knowledge markets have in circulation products connected with knowledge which include the following: intellectual property rights (mainly patents), software, plans, projects, samples, imitating, 'disassembly methods' knowledge carriers - CDs, books, video tapes etc. (Probst et al. 2002). One of the frequent problems of knowledge acquisition is the employees' rejection of knowledge that does not come from the organization. New knowledge may undermine their previous perception of reality, which is why they choose not the best solutions but their own even though they are worse that other solutions.

\section{The use of internal and external sources of knowledge in the light of the survey results}

In 2012 the study was conducted among working people who held at least secondary education. Overall 600 questionnaires were distributed. 484 questionnaires were correctly filled, giving a return of $80,7 \%$. The spatial scope of the survey covered subregion of Słupsk, located in the central part of Middle Pomerania, northern Poland. The subject of the survey was knowledge management in organizations. The purpose of the study was to gain respondents opinions on the subject of knowledge management concept and information on the state of knowledge management in organizations. The study also had a practical purpose, namely the conclusions of the study were used to create a practical model of knowledge management in organizations. One of the questions included in the questionnaire concerned the issue of using internal and external knowledge sources by the respondents.

Table 1. Internal sources of knowledge and their application

\begin{tabular}{|r|l|c|c|c|}
\hline \multirow{2}{*}{ No. } & \multirow{2}{*}{ Internal sources of knowledge } & \multicolumn{3}{c|}{ Average rating } \\
\cline { 3 - 4 } & & \multicolumn{2}{c|}{ Position } & \multirow{2}{*}{ Altogether } \\
\cline { 3 - 4 } & & managerial & non-managerial & \\
\hline 1 & the closest coworkers & 3,31 & 3,60 & 3,51 \\
\hline 2 & employees of other departments & 2,66 & 2,52 & 2,56 \\
\hline 3 & Superiors & 3,33 & 3,14 & 3,19 \\
\hline 4 & internal instructions, manuals and regulations & 2,25 & 3,01 & 3,08 \\
\hline 5 & Intranet & 2,25 & 2,28 & 2,39 \\
\hline 6 & internal communication platforms & 2,93 & 1,88 & 1,99 \\
\hline 7 & staff meetings (notes) & 2,30 & 2,15 & 2,37 \\
\hline 8 & database containing employees' experiences and skills & 2,22 & 1,73 & 1,89 \\
\hline 9 & database of reports on tasks and projects & 2,40 & 1,81 & 1,93 \\
\hline 10 & documents database segregated by thematic categories & 1,97 & 1,66 & 2,09 \\
\hline 11 & service operating as a discussion group & & & 1,75 \\
\hline
\end{tabular}

Source: author 
As it was stated before, there are a number of internal and external sources, from which employees can draw the knowledge they need to solve problems, make decisions and take actions. To identify sources of knowledge, which they use most frequently, respondents were asked to assign points from 1 to 5 to the sources listed in the question, where 1 point meant: I don't use this source of knowledge, and 5 points meant: I use this source of knowledge very often. Then, for each source of knowledge an average frequency of its use was calculated.

Considering the internal sources of knowledge (Table 1) respondents most often used the knowledge of their closest coworkers $(3,51)$, superiors $(3,19)$, as well as internal instructions, manuals and regulations $(3,08)$. On the other hand, the rarest among the internal sources used by questionnaire participants were: service operating as a discussion group $(1,75)$, database containing the employees' experiences and skills $(1,89)$, database of reports on tasks and projects $(1,93)$ and internal communication platforms $(1,99)$.

In a situation when the organization's knowledge resources are insufficient to solve a particular problem, make a decision or take action, there are two possible solutions: development of necessary knowledge within organization (which can be a lengthy and expensive process) or taking advantage of external sources of knowledge (Table 2).

Table 2. External knowledge sources and their application

\begin{tabular}{|c|c|c|c|c|}
\hline \multirow{3}{*}{ No. } & \multirow{3}{*}{ External knowledge sources } & \multicolumn{3}{|c|}{ Average rating } \\
\hline & & \multicolumn{2}{|c|}{ Position } & \multirow{2}{*}{ Altogether } \\
\hline & & managerial & non-managerial & \\
\hline 1 & seminars, conferences & 2,78 & 1,74 & 2,04 \\
\hline 2 & Legislation & 2,99 & 2,36 & 2,54 \\
\hline 3 & Exhibitions & 1,64 & 1,38 & 1,45 \\
\hline 4 & sharing best practices & 2,39 & 1,71 & 1,91 \\
\hline 5 & business intelligence & 2,03 & 1,48 & 1,63 \\
\hline 6 & external knowledge databases & 2,45 & 2,08 & 2,19 \\
\hline 7 & professional publications & 2,93 & 2,45 & 2,59 \\
\hline 8 & Customers & 2,99 & 2,52 & 2,65 \\
\hline 9 & Suppliers & 2,99 & 2,12 & 2,37 \\
\hline 10 & cooperating organizations & 2,45 & 1,94 & 2,78 \\
\hline 11 & business competitors & 2,61 & 1,73 & 1,98 \\
\hline 12 & informal contacts & 2,70 & 2,12 & 2,29 \\
\hline 13 & consulting companies & 1,60 & 1,40 & 1,46 \\
\hline 14 & knowledge brokers & 1,40 & 1,23 & 1,28 \\
\hline 15 & market research agencies & 1,36 & 1,36 & 1,36 \\
\hline 16 & research institutes, universities & 1,79 & 1,49 & 1,57 \\
\hline 17 & Politicians & 1,55 & 1,26 & 1,34 \\
\hline 18 & Media & 2,39 & 2,24 & 2,28 \\
\hline 19 & Internet & 3,88 & 3,64 & 3,71 \\
\hline 20 & Patents & 1,69 & 1,50 & 1,55 \\
\hline 21 & Software & 2,93 & 2,45 & 2,58 \\
\hline 22 & patterns, projects & 2,33 & 2,11 & 2,17 \\
\hline 23 & people from outside the organization (potential employees) & 2,03 & 1,79 & 1,86 \\
\hline
\end{tabular}

Source: author

Considering external knowledge sources, listed in the question, the most commonly used was the Internet $(3,71)$, followed by: cooperating organizations $(2,78)$, customers $(2,65)$, professional publications $(2,59)$, software $(2,58)$ and legislation $(2,54)$. On the other hand the least popular external sources of knowledge among 
respondents include: knowledge brokers $(1,28)$, politicians $(1,34)$, market research agencies $(1,36)$, exhibitions $(1,45)$ and consulting companies $(1,46)$.

In general, people occupying managerial positions use both internal and external knowledge sources more often. In case of managers the average for all types of internal knowledge sources listed in the question was 2,66 and for external sources - 2,34, while for employees occupying non-managerial positions it was 2,34 and 1,92 respectively. The results of the study explicitly indicate on the fact, that in practice employees use mainly the closest internal sources of knowledge.

\section{Internal or external knowledge?}

At this point the question arises: which sourcesof knowledge - internal or external - are more important in terms of their impact on the competitiveness of the organization? A definite answer to this question can not be given. Internal knowledge is developed under the specific needs of a particular organization. When protected against competitors in the industry, internal knowledge can enable the organization to achieve a competitive advantage in the market in the long term. As Loree et al. (2011) stated, the organization that originally created the knowledge understands it better and is more likely to realize performance benefits than the organization that acquired it from external sources. However, the development of internal knowledge of the organization usually requires more time than the acquisition of knowledge from external sources. Sometimes this process is also more costly option for the organization.

Organizations which base their competitive advantage on internal knowledge should use all reasonable endeavours to protect it from competitors and to preserve it. In many organizations previously created concepts and solutions fall into oblivion or nobody knows where to find them (Figurska, Próchniak 2013). Employees who leave the organization take their tacit knowledge with them, which causes knowledge gaps in the organization. Decisions regarding restructuring, reduction, reorganization etc. are made without taking into consideration the fact that valuable knowledge resources can be lost. All these situations show that lack of organizational memory can cause numerous problems for organizations and its members. In order to prevent the loss of organizational memory organizations should be involved in the process of knowledge preservation (Figurska 2012).

Organizations can create innovations not only by creating and using internal knowledge, but also by acquiring external knowledge and applying it to their particular situation. Zack (2005) emphasized that external knowledge is important to firm innovation processes, because:

- integration of external knowledge allows firms to create new knowledge and thus close internal knowledge gaps and external competitive gaps,

- the use of external knowledge avoids the risk of an overreliance on internal knowledge, thus avoiding learning traps.

To acquire and apply external knowledge organizations need to interact with and monitor the environment for sources of external knowledge. Deciding to acquire knowledge from external sources one should take into account (Loree et al. 2011):

a) risk that relates primarily to assimilating that knowledge either improperly or inadequately,

b) costs of:

- scouting the environment and searching for appropriate knowledge the organization can use,

- bargaining and evaluating the pros and cons of each technology developed outside the organization,

- monitoring an enforcing the agreements organizations made with other companies that are related to acquiring the knowledge they find useful.

According to the authors mentioned above, acquiring external knowledge by the organization might provide competitive parity but not competitive advantage, because competitors can often acquire the same knowlede just 
as easily. To identify the impact of the external knowledge acquisition and use on the organizations' performace, they carried out a research, which results indicate that (Loree et al. 2011):

- organizations that use external knowledge extensively while simultaneously implementing new-product market entries benefit much less from external knowledge that companies that make fewer new-product market entries,

- organizations with a higher absorptive capacity, which is understood as a fundamental learning process related to a company's ability to acquire and apply knowledge, can use external knowledge effectively and realize expected performance benefits.

It is also worth remembering that knowledge acquired from the environment is strongly dependent on the context in which it is used, therefore, transferring it form one organization to another may decrease the possibility of its further and effective use.These conclusions show that the use of knowledge from external sources not always brings the organization expected benefits. On the other hand, the use of internal knowledge solely decreases ability of the organization to exploit opportunities and to counter threats emerging in the environment. The fact that organizations conduct both internal and external knowledge acquisition activities simultaneously suggests that these activities are complementary, i.e., the marginal return to one activity increases as the intensity of the others increases (Cassiman, Veugelers 2006). Both types of knowledge sources are important for the company because they are mutually interdependent and complementary learning processes.

\section{Procedure of identification and exploitation of knowledge sources}

The fact, that in practice employees use mainly the closest internal sources of knowledge, can be caused by various factors, such as:

- lack of some of the knowledge sources available,

- restricted access to the selected knowledge sources,

- lack of information on knowledge sources available for employees,

- slight informational usefulness of the knowledge sources,

- lack of motivation for using the knowledge sources.

Identification of above-mentioned barriers to the use of knowledge sources is the first step on the way to their liquidation. Application of procedure presented in figure 2 may help in this process.

First of all one information requirements of employees should be determined. Then one should examine which knowledge sources are available for the employees of the organization. If accessible for the employees' knowledge sources are of high information usefulness and they use them very often - the sources should be further disseminated in the organization. However, if the identified sources of knowledge are not used or are used by the employees hardly ever, it is necessary to discover the causes of that fact in order to overcome identified barriers (e.g. by training courses, changing the organization of work, implementing modern computer tools) and finally - to disseminate these knowledge sources in the organization. If the available for employees' knowledge sources satisfy merely a part of their needs, then on the one hand these sources should be disseminated in the organization and, on the other hand, new and useful knowledge sources should be acquired. In case of identifying that knowledge sources available in the organization are useless for employees, these sources should be no longer used.

However, if the sources which might satisfy employees' information needs were not identified, one should characterize the causes for the lack of their accessibility (i.e. too high implementation related and/or maintenance related costs) and then to make any effort in order to obtain the access to new knowledge sources which are of high information usefulness character.

DETERMINATION OF EMPLOYEES' INFORMATION REQUIREMENTS 


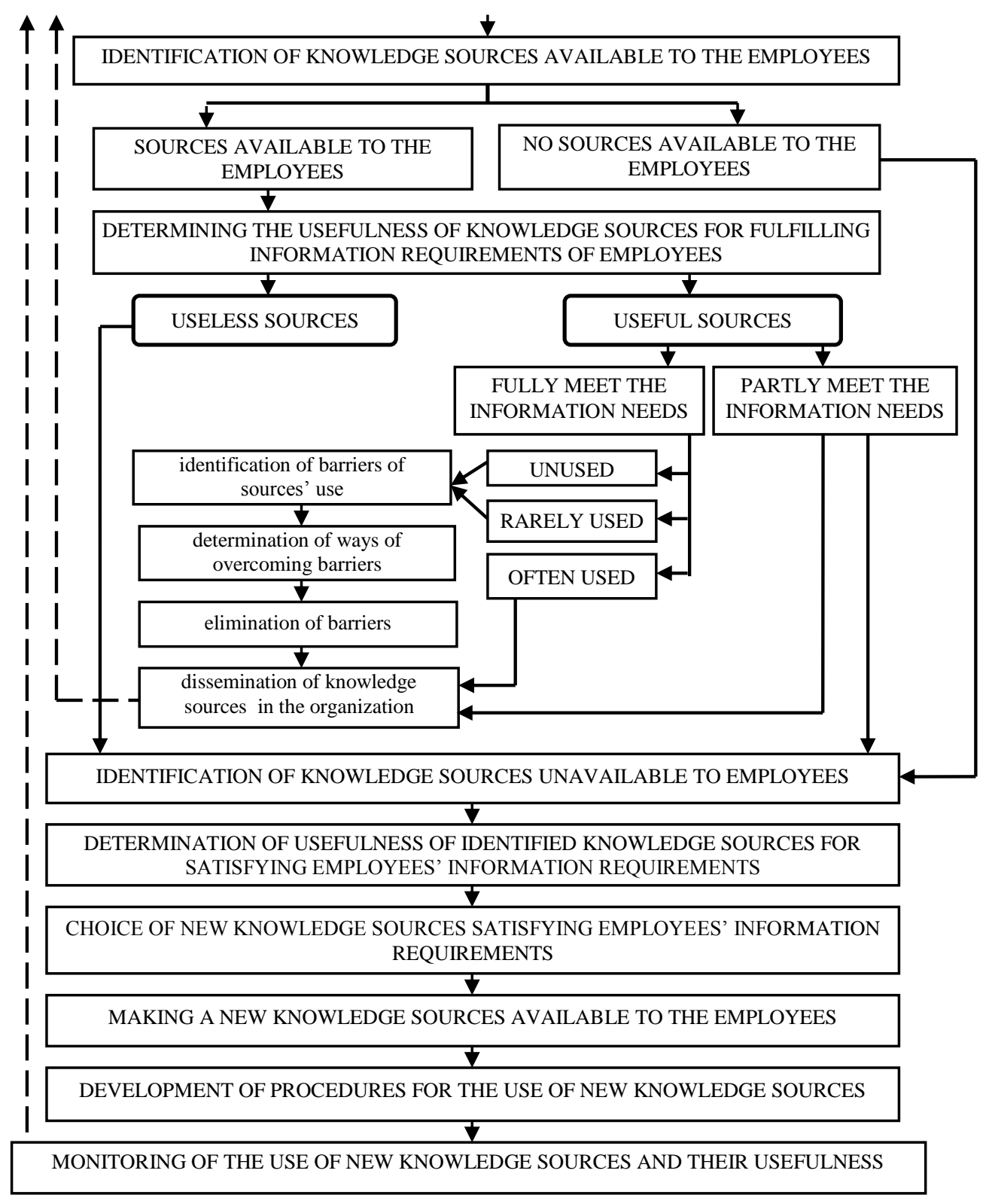

Fig.2. Knowledge sources and their use

Source: author

The process of acquisition new knowledge sources ought to be started with identification of sources unavailable for employees as well as with determining the fact if and to what degree they can satisfy employees' information needs. After that an extensive selection of the best for the organization knowledge sources should be made while taking into account such criteria as: the cost of obtaining them, the financial capability of the organization as far as keeping them up-to-date is concerned, etc. Having chosen and acquired the selected sources of knowledge, one should make them accessible for employees, create procedures governing the use of the sources and then monitor the using as well as the effectiveness of the obtained sources of knowledge.

\section{Conclusions}


Knowledge management plays important role in building of competitiveness through sustainable entrepreneurship. There are numerous external and internal sources of knowledge, from which employees might exploit the knowledge that is necessary for solving problems that occur in the organization. On the one hand, the number of sources gives the employees a lot of opportunities. On the other hand, the dispersion of the sources poses a great problems related to finding and selecting the most useful ones. Thus, in organizations that to manage knowledge effectively it is worth devoting one's attention to making the sources of external and internal knowledge more common, that is to creating knowledge transparency in organizations.

It is not possible to determine unambiguously which knowledge - internal or external - is more important for organizations in the context of building their competitive advantage in the market. It depends on many factors specificity of the organization, their business strategy and knowledge strategy, situation on the market etc. On the one hand, organization can not build its competitive advantage solely on the basis of internal knowledge, because it does not operate in the emptiness and is influenced by a wide variety of economic, political, social and other factors coming from the environment. On the other hand, organizations can not build their competitive advantage based solely on knowledge derived from external sources, as they are also available to other market players. Only a combination of internal company's knowledge with external knowledge in unique, specific to the particular organization way, and then its effective use in everyday activities can allow the organization to gain advantage over competitors.

For many organizations selection of the most appropriate sources of knowledge may be a problem. What is taken into consideration while choosing a given source is its credibility, ability to adjust to the informational needs of an entity and the form it is presented in? Thus it is a key decision what knowledge from external sources should be acquired so that when combined together with current knowledge of the organization it could give the greatest possible synergy effects.

Employees who are expected to use knowledge from different sources should be open to new ideas as well as build and nurture good relations with clients, suppliers and other stakeholders. As confirmed by the results of the research, the easier access to a given source of knowledge the better chance of using this knowledge in various activities for organization and employees' benefit. Therefore managers should secure the access to upto-date internal and external knowledge sources for the employees and motivate them to use these sources of knowledge.

\section{References}

Antanavičienè, J. 2014. Foreign direct investment: driving factors and outcomes for secure and sustainable development, Journal of Security and Sustainability Issues 3(3): 55-67. DOI: http://dx.doi.org/10.9770/jssi.2014.3.3(5)

Baikovs, A.; Zariņ̌̌, I. 2013. Philosophical, legal and general issues of legal liability, Entrepreneurship and Sustainability Issues 1(1): 23-36. DOI: http://dx.doi.org/10.9770/jesi.2013.1.1(3)

Balkienè, K. 2013. Sustainable innovativeness: issues and public policy, Journal of Security and Sustainability Issues 3(2): 53-76. DOI: http://dx.doi.org/10.9770/jssi.2013.3.2(5)

Bhati, A.; Manimala, M. J. 2011. Talent acquisition and retention in social enterprises, Journal of Security and Sustainability Issues 1(1): 37-51. DOI: http://dx.doi.org/10.9770/jssi.2011.1.1(4)

Bileišis, M. 2014. Public Sector Control as a Factor in Entrepreneurial Policy: the Case of Lithuania, Entrepreneurship and Sustainability Issues 1(3): 151-161. DOI: http://dx.doi.org/10.9770/jesi.2014.1.3(4)

Cassiman, B.; Veugelers, R. 2006. In Search of Complementarity in Innovation Strategy: Internal R\&D and External Knowledge Acquisition, Management Science 1(52): 68-82.

Caurkubule, Ž.; Rubanovskis, A. 2014. Pension system development and the sustainability of the principle of generation solidarity, Entrepreneurship and Sustainability Issues 1(3): 173-186. DOI: http://dx.doi.org/10.9770/jesi.2014.1.3(6) 
De Alencar, L.M.; Almeida, H.N. 2013. Economic viability and sustainability of solidarity economy enterprises: a case study on the technological incubator of popular cooperatives of the Catholic University of Salvador, Entrepreneurship and Sustainability Issues 1(2):92-98. DOI: http://dx.doi.org/10.9770/jesi.2013.1.2(3)

Dudzevičiūtè, G. 2012. Conceptual approaches towards sustainability, Journal of Security and Sustainability Issues 1(4): 261-272. DOI: http://dx.doi.org/10.9770/jssi.2012.1.4(3)

Dudzevičiūtè, G. 2013. Lithuanian manufacturing trends in the context of developed and developing countries, Entrepreneurship and Sustainability Issues 1(1): 55-66. DOI: http://dx.doi.org/10.9770/jesi.2013.1.1(6)

Dudzevičiūtè, G.; Tvaronavičienè, M. 2011. Measurement framework of innovation activity: theoretical approaches' analysis, Journal of Security and Sustainability Issues 1(1): 61-73. DOI: http://dx.doi.org/10.9770/jssi.2011.1.1(6)

Eppler, M. J. 2004. Making Knowledge visible through knowledge maps: concepts, elements, cases, in Holsapple C.W. (Ed.). Handbook on Knowledge Management. New York, Springer Berlin Heidelberg, 189-205.

Eppler, M. J.; Burkhard, R. A. 2007. Visual representations in knowledge management: framework and cases, Journal of Knowledge Management 4(11): 112-122.

Ercsey, I. 2012. Perceived quality of life as sustainable development facet, Journal of Security and Sustainability Issues 2(2): 19-30. DOI: http://dx.doi.org/10.9770/jssi.2012.2.2(2)

Figurska, I. 2012. Zarządzanie wiedzą w organizacji [Knowledge management in the organization], Slupsk: Published by Higher Hanseatic School of Management.

Figurska, I.; Próchniak, A. 2013. Knowledge management preservation in the organization in theory and practice, in Human Potential Development. Proceedings of Scientific Papers. University of Žilina, 104-112.

Galan-Ladero, M.M.; Galera-Casquet, C.; Valero-Amaro, M. V.; Jesus Barroso-Mendez, J. 2013. Sustainable, socially responsible business: the cause - related marketing case. a review of the conceptual framework, Journal of Security and Sustainability Issues 2(4): 35-46. DOI: http://dx.doi.org/10.9770/jssi.2013.2.4(4)

Giriūnienè, G. 2013. Public sector's subsidies to business - suitability valuation of labor market support measures, Entrepreneurship and Sustainability Issues 1(1): 37-44. DOI: http://dx.doi.org/10.9770/jesi.2013.1.1(4)

Grybaitè, V. 2011. Towards measurement of sustainable development: systems of indicators, Journal of Security and Sustainability Issues 1(1): 17-24. DOI: http://dx.doi.org/10.9770/jssi.2011.1.1(2)

Išoraitè, M. 2013. Motivation tools though lenses of prospective employees, Entrepreneurship and Sustainability Issues 1(2): 116123. DOI: http://dx.doi.org/10.9770/jesi.2013.1.2(6)

Korsakienè, R.: Baranauskienè, A. 2011. Factors impacting sustainable internationalization: a case of multinational company, Journal of Security and Sustainability Issues 1(1): 52-60. DOI: http://dx.doi.org/10.9770/jssi.2011.1.1(5)

Kowalczyk, A.; Nogalski, B. 2007. Zarządzanie wiedzą. Koncepcja i narzędzia [Knowledge management. Concept and tools], Warsaw: Published by Difin.

Lankauskienè, T.; Tvaronavičienè, M. 2012. Security and sustainable development approaches and dimensions inn the globalization context, Journal of Security and Sustainability Issues 1(4): 287-297. DOI: http://dx.doi.org/10.9770/jssi.2012.1.4(5)

Laužikas, M.; Dailydaite, S. 2013. Benefits of social capital for sustainable innovation capabilities, Journal of Security and Sustainability Issues 2(3): 85-97. DOI: http://dx.doi.org/10.9770/jssi.2013.2.3(7)

Laužikas, M.; Krasauskas, A. 2013. Impacts of sustainable structural growth on the economic performance of listed companies, Entrepreneurship and Sustainability Issues 1(2): 81-91. DOI: http://dx.doi.org/10.9770/jesi.2013.1.2(2)

Laužikas, M.; Mokšeckienè. 2013. The role of creativity in sustainable business, Entrepreneurship and Sustainability Issues 1(1): 10-22. DOI: http://dx.doi.org/10.9770/jesi.2013.1(2)

Lavrinovich, I.; Lavrinenko, O.; Jefimovs, N. 2012. Sustainable development, economic growth and differentiation of incomes of Latvian population, Journal of Security and Sustainability Issue 2(1): 33-39. DOI: http://dx.doi.org/10.9770/jssi/2012.2.1(3)

Loree, D.; Bapuji, H.; Crossan, M. 2011. Relying on external knowledge for competitive advantage: Why it might not work. Available on the Internet: <http://iveybusinessjournal.com/topics/the-organization/relying-on-external-knowledge-for-competitive-advantage-why-itmight-not-work\#.UzsRSWOZiM8>. 
Mačiulis, A.; Tvaronavičienè, M. 2013. Secure and sustainable development: Lithuania's new role in taking the Presidency of the EU, Journal of Security and Sustainability Issues 3(2): 5-13. DOI: http://dx.doi.org/10.9770/jssi.2013.3.2(1)

Makštutis, A.; Balkytė, A.; Tumalavičius, V. 2012. Security, Sustainability and Competitiveness: Benchmarking attempts, Journal of Security and Sustainability Issues 2(1): 5-12. DOI: http://dx.doi.org/10.9770/jssi/2012.2.1(1)

Moskvina, J. 2013. Social enterprises as a tool of social and economic policy, Entrepreneurship and Sustainability Issues 1(1): 4554. DOI: http://dx.doi.org/10.9770/jesi.2013.1.1(5)

Pepper, S. E. 1999. Topic Maps, and Revolution. Available on the Internet: 〈http://www.infoloom.com/tmsample/pep4.htm>.

Prause, G.; Hunke, K. 2014. Sustainable entrepreneurship along green corridor, Entrepreneurship and Sustainability Issues 1(3): 124133. DOI: http://dx.doi.org/10.9770/jesi.2014.1.3(1)

Probst, G.; Raub, S.; Romhardt K. 2002. Zarządzanie wiedzą w organizacji [Knowledge management in the organization]. Krakow: Published by Oficyna Ekonomiczna [Economic Publishing House].

Radović Marković, M. 2011. Critical employment analysis: theory, methodology and research, Journal of Security and Sustainability Issues 1(2): 113-121. DOI: http://dx.doi.org/10.9770/jssi.2011.1.2(4)

Raišienè, A.G. 2012. Sustainable development of interorganizational relationships and social innovations, Journal of Security and Sustainability Issues 2(1): 65-76. DOI: http://dx.doi.org/10.9770/jssi/2012.2.1(6)

Raišienè, A.G.; Jonušauskas, S. 2013. Silent issues of ICT era: impact of techno-stress to the work and life balance of employees, Entrepreneurship and Sustainability Issues 1(2):108-115 DOI: http://dx.doi.org/10.9770/jesi.2013.1.2(5)

Rigby, D.; Zook, C. 2002. Open-market innovation, Harvard Business Review 80(10): 80-89.

Šileika, A.; Bekerytè, J. 2013. The theoretical issues of unemployment, poverty and crime coherence in the terms of sustainable development, Journal of Security and Sustainability Issues 2013 2(3): 59-70. DOI: http://dx.doi.org/10.9770/jssi.2013.2.3(5)

Sopińska, A.; Wachowiak, P. 2006. Autorski model zarządzania wiedzą w przedsiębiorstwie [Author's model of knowledge management in the company], E-mentor 3(15): 48-56.

Sopińska, A.; Wachowiak, P. 2006. Modele zarządzania wiedzą w przedsiębiorstwie [Models of knowledge management in the company], E-mentor 1(8): 55-59.

Stańczyk, J. 2011. European security and sustainability issues in the context of current international environment, Journal of Security and Sustainability Issues 1(2): 81-90. DOI: http://dx.doi.org/10.9770/jssi.2011.1.2(1)

Tiwana, A. 2003. Przewodnik po zarządzaniu wiedzą, e-biznes i zastosowania CRM [Guide to knowledge management, e-business and CRM applications], Warsaw: Published by Placet.

Tvaronavičienè, M. 2012. Contemporary perceptions of energy security: policy implications, Journal of Security and Sustainability Issues 1(4): 235-247. DOI: http://dx.doi.org/10.9770/jssi.2012.1.4(1)

Tvaronavičienè, M. 2014. If industrial sector development is sustainable: Lithuania compared to the EU, Entrepreneurship and Sustainability Issues 1(3): 134-142. DOI: http://dx.doi.org/10.9770/jesi.2014.1.3(2)

Tvaronavičienė, M.: Grybaitè, V.:Tunčikienè, Ž. 2013. Globalization drivers in developed and less developed countries: if consistent patterns can be traced, Journal of Security and Sustainability Issues 2(4): 5-11. DOI: http://dx.doi.org/10.9770/jssi.2013.2.4(1)

Tvaronavičienè, M.; Grybaitè, V. 2012. Sustainable development and performance of institutions: approaches towards measurement, Journal of Security and Sustainability Issues 1(3): 167-175. DOI: http://dx.doi.org/10.9770/jssi/2012.1.3(2)

Tvaronavičienè, M.; Lankauskienè, T. 2011. Plausible foreign direct investment‘ impact on sustainable development Indicators of differently developed countries, Journal of Security and Sustainability Issues 1(1): 25-36. DOI: http://dx.doi.org/10.9770/jssi.2011.1.1(3)

Tvaronavičienè, M.; Lankauskienè, T. 2013. The impact of production factors and economic structures on economic development, Business: Theory and Practice 14(1): 5-16. DOI: 10.3846/bpt.2013.06

Vasiliūnaite, R. 2014. Sustainable development: methodological approaches toward issues, Journal of Security and Sustainability Issues 3(3): 69-75. DOI: http://dx.doi.org/10.9770/jssi.2014.3.3(6) 
Vosylius, E.; Rakutis, V.; Tvaronavičienè, M. 2013. Economic growth, sustainable development and energy security interrelation, Journal of Security and Sustainability Issues 2(3): 5-14. DOI: http://dx.doi.org/10.9770/jssi.2013.2.3(1)

Wachowiak, P. 2009. Mapowanie wiedzy w przedsiębiorstwie [Knowledge mapping in the company], E-mentor 1(28): 61-64 .

Wahl, M.; Prause, G. 2013. Toward understanding resources, competencies, and capabilities: business model generation approach, Entrepreneurship and Sustainability Issues 1(2): 67-80. DOI: http://dx.doi.org/10.9770/jesi.2013.1.2(1)

Zack, M. 2005. The Strategic Advantage of Knowledge and Learning, International Journal of Knowledge and Learning 1(2): 1-20.

Irena Figurska, PhD, works in Pomeranian University in Stupsk, Poland. She also lectures at the Higher Hanseatic School of Management in Słupsk and Social Academy of Sciences in Łódź. She is an expert in knowledge management and human resources management. She is an author of more than 50 articles published in Poland and abroad as well as monographs, chapters in monographs and university handbooks. She is a co-editor of a few scientific papers. Research interests: knowledge management, human resources management, competitiveness in regional aspects, problems of labour market.

(cc) $\mathbf{E Y}$ This work is licensed under a Creative Commons Attribution 3.0 License. 